\title{
Effect of COVID-19 lockdown on the water quality index of River Gomti, India, with potential hazard of faecal-oral transmission
}

\author{
Ramsha Khan $^{1}$ (D) $\cdot$ Abhishek Saxena $^{1}$ (D) $\cdot$ Saurabh Shukla ${ }^{1}$ (D) $\cdot$ Selvam Sekar $^{2}$ (I) $\cdot$ Pooja Goel $^{3}$ (I)
}

Received: 25 November 2020 / Accepted: 18 February 2021 / Published online: 26 February 2021

(C) The Author(s), under exclusive licence to Springer-Verlag GmbH, DE part of Springer Nature 2021

\begin{abstract}
The COVID-19 lockdown has been reported as a "ventilator" for the reinstatement of natural resources across the globe. Hence, the present study attempts to evaluate the impact of COVID-19 lockdown on the water quality of River Gomti across its stretch of $\sim 960 \mathrm{~km}$ through the assessment of 'Water Quality Index' (WQI). The study also highlights the potential risk of faecal-oral transmission of COVID-19 through intake of river water facing the issue of direct discharge of domestic sewage. A deterioration in the water quality was witnessed at $\sim 69 \%$ sampling locations during the lockdown period (May 2020). Interestingly, none of the water samples during the pre-lockdown, lockdown, and post-lockdown periods across the whole stretch belonged to the "excellent" category (WQI $<25$ ). The DO levels fell across $\sim 69 \%$ and $\sim 88 \%$ of the sites during the lockdown and post-lockdown periods, respectively. Moreover, there was an increase in the $\mathrm{BOD}_{5}$ levels across $\sim 69 \%$ and $75 \%$ of the sites during lockdown and post-lockdown periods, respectively. These findings indicate that the release of sewage without or with partial treatment is a chief contributor of water pollution in the groundwater fed River Gomti. Thereby, highlighting the possible risk of faecal-oral transmission of the corona virus, and creating a major concern for the residents across its stretch. The urban sprawl and riverfront development in Lucknow city also emerge as potential causes of water quality deterioration in River Gomti, considering that the water quality at five sites within the city was under the "unfit" category regardless of the lockdown situation. Thus, the urgent need of management of domestic sewage release into the river and further research on the potential risk of faecal-oral transmission of COVID-19 have been suggested in the study.
\end{abstract}

Keywords COVID-19 $\cdot$ Faecal-oral transmission $\cdot \mathrm{BOD}_{5} \cdot$ Water quality index $\cdot$ Gomti River Basin (GRB)

Responsible Editor: Lotfi Aleya

Abhishek Saxena

abhisheksaxena79@gmail.com

Ramsha Khan

ramshaokhan@gmail.com

Saurabh Shukla

saurabh.shukla2020@gmail.com

Selvam Sekar

geoselvam10@gmail.com

Pooja Goel

goelpooja78@rediffmail.com

1 Faculty of Civil Engineering, Institute of Technology, Shri Ramswaroop Memorial University, Barabanki, UP 225003, India

2 Department of Geology, V.O. Chidambaram College, Tuticorin, Tamil Nadu, India

3 Centre of Advanced Study in Geology, University of Lucknow, Lucknow 226007, India

\section{Introduction}

The novel coronavirus disease (COVID-19) broke out in the months of November-December 2019 in the city of Wuhan, China, and spread across the globe at a very rapid pace (Yunus et al. 2020). The disease caused by severe acute respiratory syndrome coronavirus 2 (SARS-CoV-2) has affected more than thirty million people with more than 1 million deaths around the world (Worldometer 2020a). The United Sates of America has reportedly witnessed the highest number of infected patients followed by India with more than 6.8 million cases up to the month of October 2020 (Worldometer 2020a). The absence of medicines or vaccine led to release of advisories from the World Health Organization (WHO) and various government bodies to ensure the safety of public. The advisories included the practise of social distancing, cleaning of hands, frequent temperature checks, avoiding gatherings, self-isolation in case of minor symptoms, etc. (WHO 2020a, b). A lockdown across the globe was imposed to prevent the 
outbreak of the disease since February 2020 at various levels and stages (Yunus et al. 2020). The risk and potential hazard associated with the outbreak of COVID-19 specifically in developing nations was a huge matter of concern. In India, a nationwide lockdown was declared in the evening of $24^{\text {th }}$ March 2020 and extended in phases till $31^{\text {st }}$ May 2020 to prevent the outbreak of COVID-19 amongst a population of $\sim 1.38$ billion (Worldometer 2020b) as illustrated in the Fig. 1 .

The assessment of the various effects of COVID-19 lockdown on our environment has emerged as a huge topic of interest for researchers across the globe. Our environment has potential competence to reinstate into its pristine or near pristine form, which was reportedly witnessed in the lockdown period. The reports of positive impact of lockdown have emerged as a potential remedial action for improving the quality of the various environmental resources. A study by Dutta et al. (2020) in the month of July stated that the National River of India "River Ganga" witnessed a significant improvement in the water quality during the lockdown. The water quality of River Ganga at Haridwar in this study was declared "fit for drinking," i.e., "Class A" designation notably, after 20 years since the formation of the state of Uttarakhand in the year 2000. However, as stated in a newspaper, DTE (2020) the water quality of five rivers (Ganga, Beas, Chambal, Sutlej, and Svarnarekha) deteriorated during the lockdown due to the release of untreated sewage into the rivers. Thus, contradictory results from various studies and reports make this study important for assessing the actual impact of COVID-19 lockdown on River Gomti.

The SARS-CoV-2 virus, the etiological agent of COVID19 , is majorly transmitted through respiratory droplets and contact routes (WHO 2020a, b). This virus utilizes angiotensin-converting enzyme (ACE2) as a receptor for its passage into human cells. The ACE2 messenger RNA is majorly conveyed in the gastrointestinal system (Heller et al.
2020). The detection of potential SARS-CoV-2 in the stools of COVID-19 patients and the presence of virus RNA in sewage have been highlighted in various studies (Wu et al. 2020; Wang et al. 2020; Ahmed et al. 2020). The release of the virus in human faeces after disappearance of all respiratory symptoms in COVID-19 has also been highlighted in study by $\mathrm{Wu}$ et al. (2020). In a study conducted by Medema et al. (2020), the detection of the virus in sewage during low prevalence of COVID-19 and the immediate necessity of sewage surveillance for monitoring of virus circulation were highlighted. The spread of virus through potential faecal-oral transmission in the unaffected population makes the sewage surveillance a very vital early warning tool for the possible increased circulation in the near winter season. Thus, the potential risk of faecal-oral transmission in River Gomti cannot be ignored, considering the use of river water for drinking purposes in many habitations along its course and the issue of direct domestic sewage release into the river.

River Gomti is a major groundwater-fed river traversing a course of $960 \mathrm{~km}$ across the Ganga Alluvial Plain through various cities and towns including Pilibhit, Shahjahanpur, Hardoi, Sitapur, Lucknow, Barabanki, Sultanpur, Jaunpur, and Ghazipur districts of Uttar Pradesh (UP) (Tangri et al. 2018). River Gomti is also a primary source of drinking water supply in various cities along its course. The excessive discharge of domestic sewage, industrial effluents from small scale and local industries, workshops etc. has deteriorated the water quality of River Gomti significantly in the capital city of Uttar Pradesh, "Lucknow." It is one of the most important cities of North India with a total population of $\sim 3$ million. Hence, this study aims at assessing the effect of lockdown on the water quality of River Gomti. The riverfront development was undertaken in Lucknow city and included shortening and straightening of the river channel by altering

Fig. 1 Phases of lockdown in India

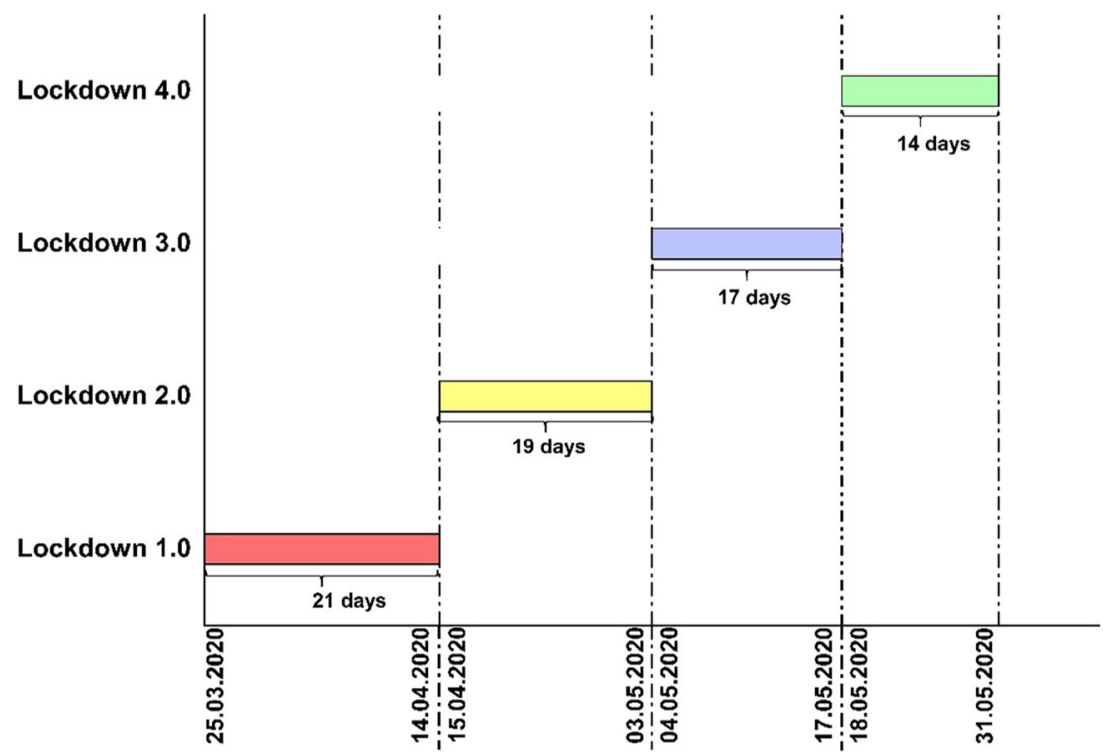


its shape, width, and riverbed, through construction of a diaphragm wall on both banks across an approximate stretch of $8 \mathrm{~km}$. The riverfront development project has been critically highlighted as another cause of water quality depletion in some previous studies (Goel et al. 2018; Dutta et al. 2018). The major variation in the water quality of the river during its passage through urban habitations has also been highlighted in a study by Khan et al. (2020). The lack of safe drinking water affects 2.2 billion people globally and insufficient access to proper sanitation facilities to 4.2 billion people. The hazard of exposure to COVID-19 through oral-faeces transmission of virus in such vulnerable situations increases even more raising the need of a detailed assessment. Hence, this study also emphasizes on the need of a comprehensive analysis considering the tenacity of viral infection in River Gomti.A comparative assessment of the water quality is carried for samples drawn during pre-COVID 19 lockdown (January 2020), during COVID-19 lockdown (May 2020), and post-COVID-19 lockdown (July 2020). Efforts have been also been made to identify possible contributing factors that are affecting the water quality.

\section{Study area}

The Gomti River Basin (GRB) is an extended basin located between $80^{\circ} 00^{\prime}-83^{\circ} 10^{\prime} \mathrm{E}$ longitude and $24^{\circ} 40^{\prime}-28^{\circ} 40^{\prime} \mathrm{N}$ latitude (Fig. 2) in the central part of Ganga Alluvial Plain (GAP), draining an area of more than $30,000 \mathrm{~km}^{2}$ in the Ghaghara-Ganga doab zone (Prakash et al. 2017). Bas-relief and mild slope exist in the GAP with its physical surface and bathymetric features, a result of the interaction between the climatic variations correlated to the base-level changes caused due to the lithospheric activities in the Quaternary Period (Srivastava et al. 2003). The GRB follows a North WestSouth East trend, nearly parallel to the Himalayas. The GRB contains various districts of UP in its lower parts including Faizabad, Raebareli, Sultanpur, Pratapgarh, Jaunpur, and various parts of Varanasi. The central segment of the basin includes the districts of Hardoi, Sitapur, Barabanki, Lucknow, and Unnao, while the upper portion of the basin includes the districts of Pilibhit, Lakhimpur Kheri, and Shahjahanpur.

The basin is primarily constituted of sediments derived from rocks of the Himalaya and Peninsula (Tangri et al. 2018). The GRB experiences semiarid to subhumid tropical climate (Das et al. 2019). The area under study is approximately a stretch of $\sim 960 \mathrm{~km}$ and consists of the following river water sampling sites: RG1: upstream Pilibhit-Pooranpur road bridge; RG2: downstream Banjaraghat, village, Sikrahana, Pooranpur; RG3: downstream Powayan Khatur road bridge; RG4: Dadhnamau Ghat, Sitapur; RG5: Manjhighat, Lucknow; RG6: upstream water intake Gaughat, Lucknow; RG7: Kudiya Ghat, Lucknow; RG8: downstream of Mohan
Meakins, Lucknow; RG9: Nishatganj Bridge, Lucknow; RG10: upstream Bairaj, Lucknow; RG11: downstream Pipraghat, Lucknow; RG12: downstream after meeting of Sewage Treatment Plant (STP), Nala Bharwara, Lucknow; RG13: upstream Sultanpur; RG14: downstream Sultanpur; RG15: downstream Gomti, Jaunpur; RG16: Gomti before meeting River Ganga, Rajwari, Varanasi. The sampling points along with location are shown in Fig. 2.

\section{Methodology}

\section{Data collection}

A comparative assessment of the variations in the water quality of the River Gomti has been attempted for the period prior to, during, and after the COVID-19 lockdown, i.e., January 2020, May 2020, and July 2020. The data on dissolved oxygen (DO), 5-day biological oxygen demand $\left(\mathrm{BOD}_{5}\right)$, and total coliform parameters available on the web portal of Uttar Pradesh Central Pollution Control Board (UPPCB 2020) was used. Due to the lockdown, all over the nation, sampling was not possible in May 2020 due to which secondary data has been used in our analysis. To maintain coherence in comparative assessment, secondary data for the months of January and July 2020 (pre and post-COVID-19 lockdown) has been used.

\section{Data treatment-Water Quality Index (WQI)}

The water quality explains the physical, chemical, and biological characteristics of water. Various water quality indices (WQI) have been developed for the monitoring and assessment of freshwater quality for human consumption. WQI is used as a defined and elaborate technique to express the quality of river water through a single number by aggregation of the values of various physicochemical parameters (Shukla and Saxena 2020b; Mishra and Kumar 2020).

The variation in the water quality parameters including $\mathrm{DO}, \mathrm{BOD}_{5}$, and total coliform at various sites was assessed and presented through graphical illustration. The water quality index (WQI) has been computed using three parameters including $\mathrm{DO}, \mathrm{BOD}_{5}$, and total coliform.

The water quality index (WQI) has been computed using weighted arithmetic index method using the following equations (Goel et al. 2018; Selvam et al. 2020; Shukla and Saxena 2020a, c):

$Q_{n}=100\left(V_{n}-V_{i}\right) /\left(V_{s}-V_{\mathrm{i}}\right)$,

where $V_{s}$ is the standard value and $V_{i}$ is the ideal value.

$W_{n}=k / S_{n}$, 

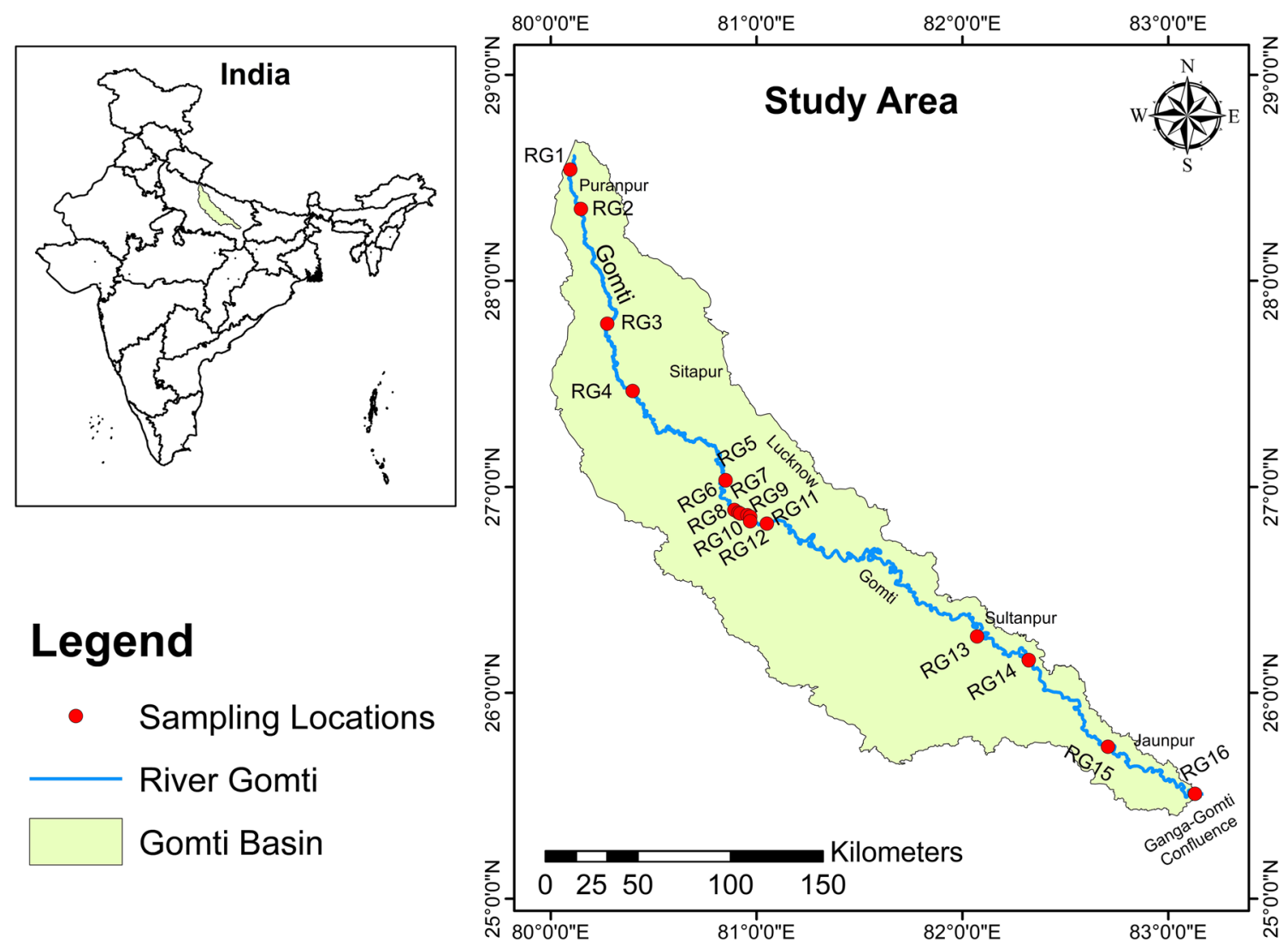

Fig. 2 Location of Gomti Basin and sampling locations

where $W_{n}$ is the unit weight for the $n$th parameter, $S_{n}$ is the standard permissible value for $n$th parameter, and $k$ is the proportionality constant.

$K=\Sigma\left(1 / S_{n}\right)$,

$\mathrm{WQI}=\frac{\sum Q_{n} W_{n}}{W_{n}}$.

The suitability of WQI values for human consumption is as follows: 0-25, excellent; 26-50, good; 51-75, bad; 76-100, very bad; and $>100$, unfit.

\section{Results and discussion}

\section{Variation in $\mathrm{DO}, \mathrm{BOD}_{5}$, and total coliform levels}

The sustenance of aquatic flora primarily depends upon DO and $\mathrm{BOD}_{5}$ levels in the surface water sources. The variation of $\mathrm{DO}$ and $\mathrm{BOD}_{5}$ levels occurs with reference to multiple factors including temperature, $\mathrm{pH}$, flow or stagnation of water, presence of organic or inorganic waste, etc. The relevance of all factors has been considered to study their impact on the variation of $\mathrm{DO}$ and $\mathrm{BOD}_{5}$ levels.
An overall average decrease of $18.2 \%$ was observed in the DO levels during the lockdown in comparison to prelockdown phase at all the sampling sites. This depletion in the DO levels could be seen in majority of the midstream (within Lucknow city) and downstream sites. The prominent effect of domestic sewage discharge on the DO levels was evident, considering that lockdown had no effect on sewage discharge. A further decrease of $18.1 \%$ occurred in the levels of DO in the post-lockdown phase. The influence of the unlocking of various anthropogenic enterprises including commercial activities, industrial effluent discharge, and small-scale enterprises emerges as a potential cause of this depletion in the post lockdown phase.

An improvement in the DO levels was witnessed during the lockdown phase at three upstream sites (RG1, RG2, and RG3) probably due to their upstream location. The presence of a treatment facility in the vicinity of two downstream sites RG11 and RG12 in Lucknow city probably contributed to the improvement in the DO levels during lockdown. The closure of anthropogenic activities including release of industrial effluents from local small-scale manufacturing units during lockdown is also a possible reason behind the increase in DO levels.

A depletion in the DO levels was witnessed from the city of Sitapur (RG4) to the sites in the urban area of Lucknow city (RG5 to RG10), along with two downstream sites RG15 and 
Fig. 3 Variation of DO levels across all sites in pre-lockdown, lockdown, and post-lockdown periods

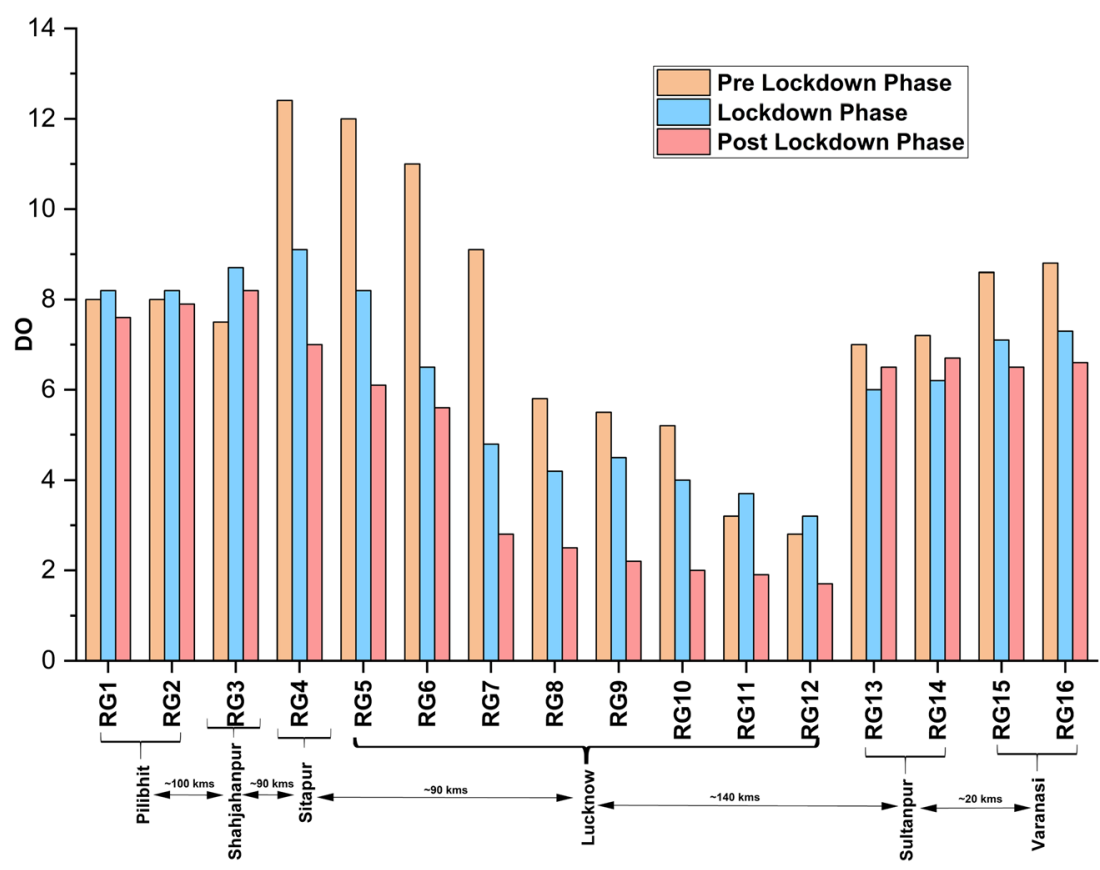

RG16 (before the confluence with River Ganga) during the lockdown as well as post-lockdown phases (Fig. 3). The potential factor of concern for water quality at these sites is domestic sewage discharge, which remained unaffected during the lockdown. Moreover, the sites RG5, RG6, RG7, RG8, RG9, and RG10, which lie within the Lucknow city, signify the operation and maintenance issues for management of domestic sewage (direct discharge into the river instead of transportation to STPs for treatment, etc.) associated with riverfront development in Lucknow city. The distance between the sampling sites within the Lucknow city is comparatively small; thereby, the effect of dilution, recovery of natural state with time, and flow are possibly reduced. The effect of unorganized settlements (slums) and livestock activities along the bank of the River Gomti might also be affecting the water quality. The decreased flow volume of the River Gomti in the city is associated with riverfront development (Dutta et al. 2018) and is another prominent factor affecting the DO levels. The depleted DO levels in the post-lockdown phase signify the effect of the unlocking of various enterprises (shopping malls, food industries, hotels, small-scale manufacturing units, garages, etc.).

The overall average values of $\mathrm{BOD}_{5}$ increased by $7.09 \%$ during the lockdown period suggesting the effect of domestic sewage load on the $\mathrm{BOD}_{5}$ levels. An average increase of $19.44 \%$ was seen in the values of $\mathrm{BOD}_{5}$ in the postlockdown duration confirming the potential effect of anthropogenic activities.

The $\mathrm{BOD}_{5}$ levels at sites RG4 to RG7, RG10, RG15, and RG16 increased during lockdown and post-lockdown periods (Fig. 4). The effect of domestic sewage discharge and anthropogenic activities at these sites might be the primary source of pollution, signifying the issue of direct discharge of sewage into the River Gomti without or with partial treatment. The sites RG5, RG6, RG7, and RG10 are in Lucknow city, and are highly affected by the domestic sewage discharge, as previously reported in some studies (Goel et al. 2018; Khan et al. 2020). The levels of $\mathrm{BOD}_{5}$ at RG8 and RG9 remained constant during lockdown and increased in the post-lockdown time. The $\mathrm{BOD}_{5}$ level at RG12 dipped slightly during lockdown and increased in post-lockdown period. The results obtained at site RG12 also signify the functioning of Bharwara STP (with a capacity of 345 MLD) in Lucknow city.

The total coliform levels decreased at $\sim 38 \%$ of the sites signifying the influence of lockdown and a reduction in various anthropogenic activities such as decreased industrial discharges from small-scale enterprises, food stalls, malls, hotels, etc. The three upstream sites (RG1, RG2, and RG3) and one downstream site (RG15) of the River Gomti witnessed constant levels of total coliform during the lockdown phase (Fig. 5). This pattern signifies the dominance of domestic sewage discharge in comparison to the industrial discharge at these sites.

A sharp decrease in the total coliform level at downstream after meeting of Sewage Treatment Plant (STP), Nala Bharwara, Lucknow (RG12), was noted during the lockdown. Since this site is in the downstream of STP (Bharwara), the decreasing level of coliform signifies the impact of lockdown and the working of STP. The increased levels of total coliform bacteria across $75 \%$ of the sites in the post-lockdown clearly show the impact of anthropogenic activities. This increase in the post-lockdown phase was prominently witnessed at seven sites within Lucknow city confirming the impact of urban sprawl and sluggish flow of River Gomti in the city. 
Fig. 4 Variation of BOD levels across all sites in pre-lockdown, lockdown, and post-lockdown periods

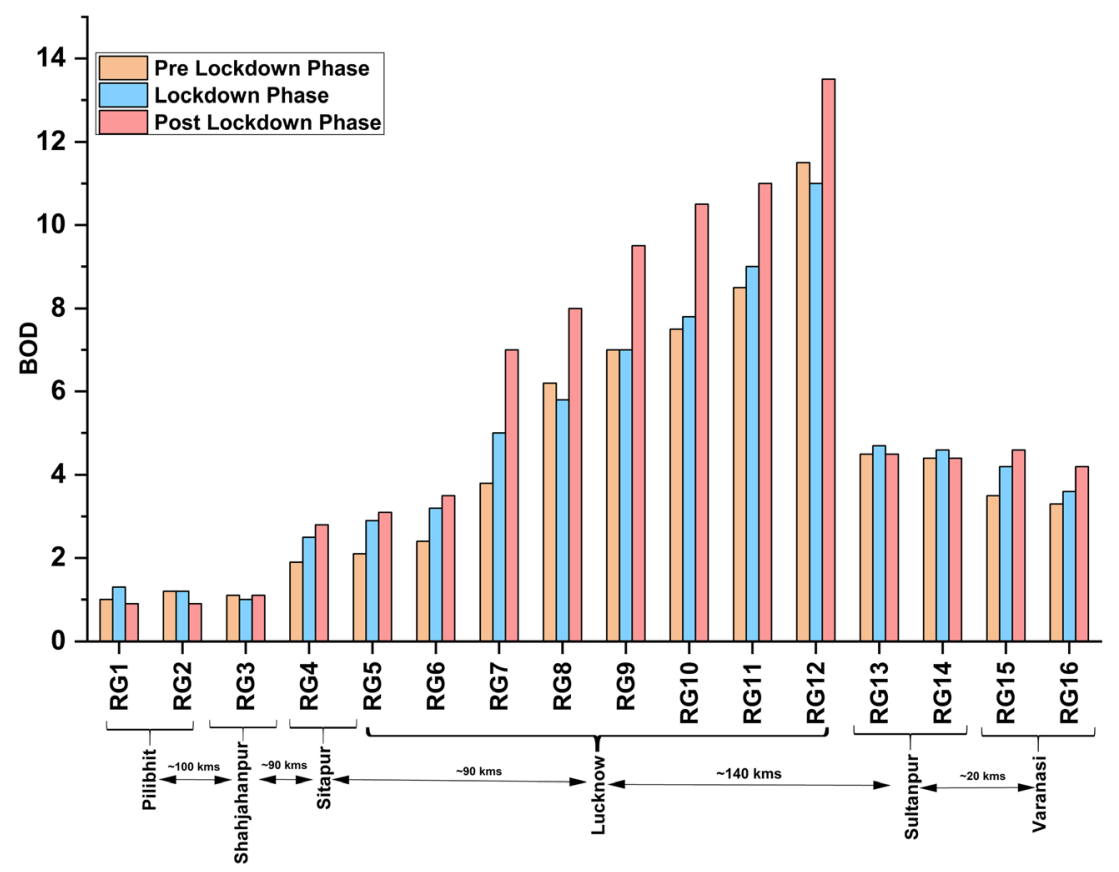

\section{Variation in WQI levels}

The WQI was computed using the values of $\mathrm{DO}, \mathrm{BOD}_{5}$, and total coliform bacteria counts. Since, only these three parameters were considered, which are very crucial for water quality of a freshwater riverine ecosystem, higher WQI values were obtained in this study. The variation of WQI at various sites in pre-COVID-19 lockdown during lockdown period and postlockdown periods is illustrated in Fig. 6. The average value of WQI increased by $0.24 \%$ and $21.36 \%$ during the lockdown phase and post-lockdown phase, respectively, showing a deterioration of water quality of the River Gomti.

The water quality during the lockdown depleted at $69 \%$ of the sites and improved at only $31 \%$ of the sites. A significant depletion in the water quality was observed at five sites within Lucknow city, signifying the effect of urban sprawl and closely located sites. River Gomti is not a glacial fed river like River Ganga; instead, it is a groundwater fed river which might have possible influence on the self-cleansing/healing capacity or ability to recover its quality. The development of
Fig. 5 Variation of total coliform at all sites in pre-lockdown, lockdown, and post-lockdown periods

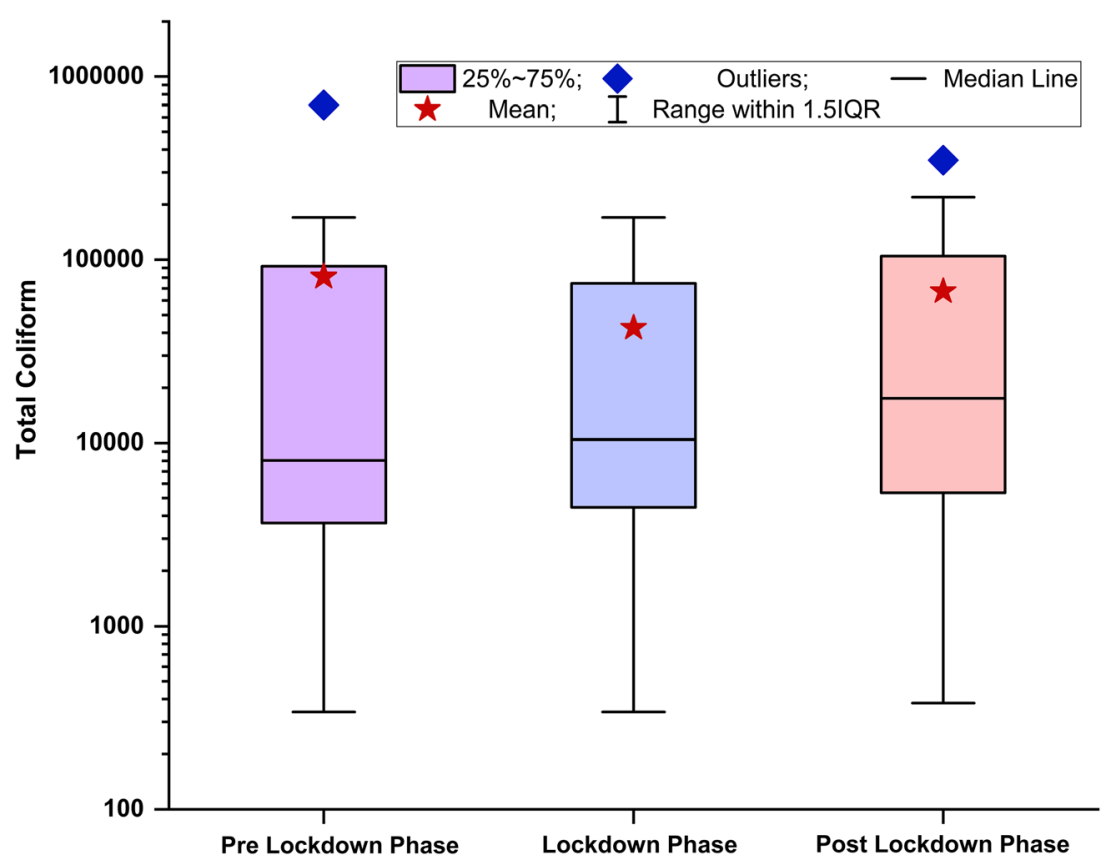


Fig. 6 Variation of water quality index across all sites in prelockdown, lockdown, and postlockdown periods

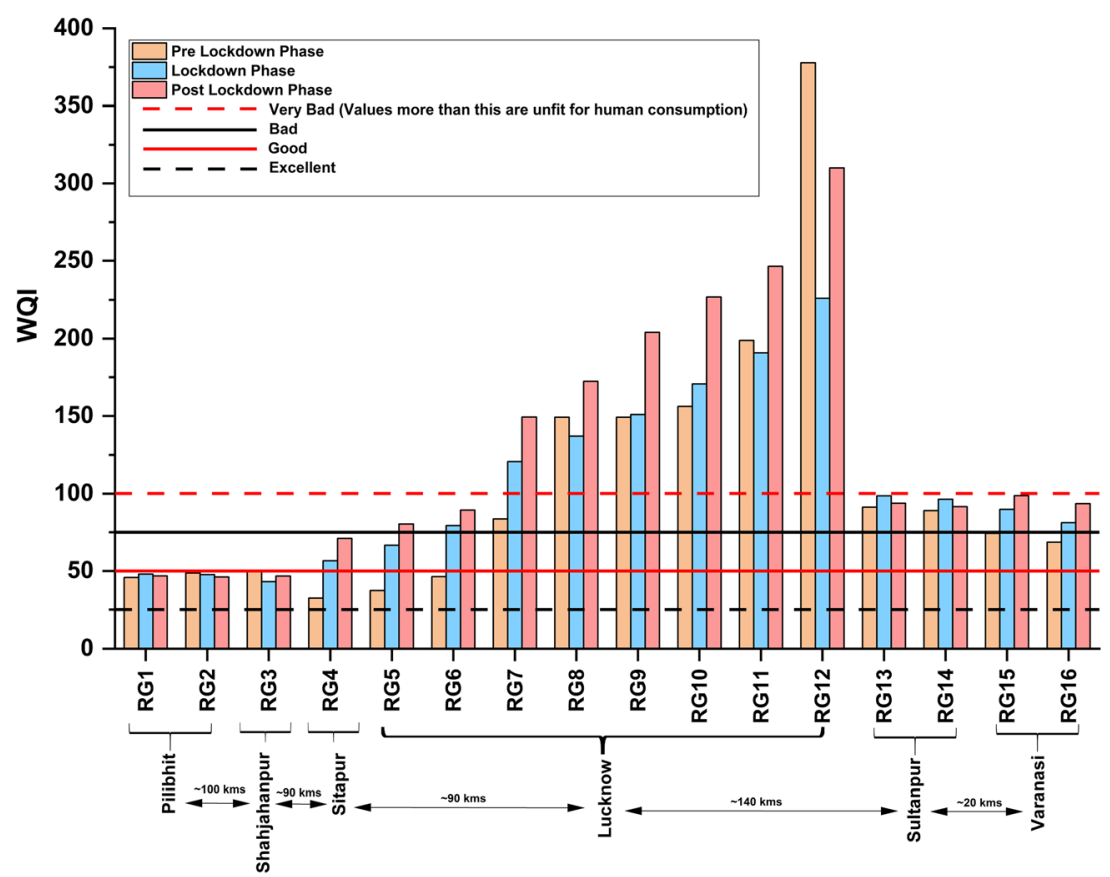

riverfront in Lucknow city appears to have a potential role in the water quality variation at the sites within the city. The impact of channel straightening and width reduction on water quality, ecological sustenance, and flow is prominent (Dutta et al. 2018).

The water quality at sites RG1, RG2, and RG3 remained in the "good" category both during the lockdown and in the postlockdown periods, suggesting lesser concentration of pollutants in the upstream sites and the influence of the selfcleaning/healing property of the river. The water quality at sites RG4, RG5, RG6, RG7, RG9, RG10, and RG16 witnessed deterioration during lockdown and further deterioration in the post-lockdown phase.

The water quality at $\sim 38 \%$ and $\sim 31 \%$ of the sites were categorized under the "unfit" and "very bad" categories during the lockdown phase, which is mainly due to the prominent impact of domestic sewage release without or with only partial treatment, while $\sim 38 \%$ of the sites were in the "unfit" and "very bad" categories each in the post-lockdown phase highlighting the influence of anthropogenic activities (reopening of food stalls, hotels, small scale industrial units, garages, etc.).

A near constant trend of increasing WQI values suggested deterioration in water quality at sites within the Lucknow city (RG5 to RG10). This finding signified the discharge of domestic sewage into the River Gomti, which remained nearly constant in all three periods (pre-COVID-19 lockdown, during COVID-19 lockdown, and post-COVID-19 lockdown). The range of WQI values for sites in Lucknow city (RG5 to RG10) varied between 37.44-156.16, 66.61-170.65, and 80.37-226.88, in pre-COVID lockdown, during lockdown, and post-lockdown periods, respectively.
A slight improvement in the water quality was observed at RG11 and RG12 during lockdown signifying the effects of lockdown and the working of Bharwara STP (capacity 345 MLD). However, the water at sites RG11 and RG12 still remained in "unfit" category with WQI value of 190.72 and 226 respectively during the lockdown.

\section{Potential hazard of faecal-oral transmission}

A study by Medema et al. (2020) in Netherlands highlighted the detection of two genes of SARS-CoV-2 in the sewage of various WWTP in coherent alignment with the emerging epidemic. The number of reported COVID-19 patients in habitations along the path of River Gomti is $\sim 0.1$ million, with alone $\sim 68,000$ cases in Lucknow city (BING 2020). The non-detection of asymptomatic patients across the globe is well known, hence raising the possibility of more patients, and associated outspread of the virus. The sewage from COVID-19 hospitals, quarantine centres, home quarantined patients, and non-detected patients raises a potential hazard of faecal-oral transmission in River Gomti witnessing the issue of direct domestic sewage discharge confirmed in the current study. Thus, this hypothesis needs an elaborate assessment through sewage surveillance to terminate the possibility of outspread of the virus in public considering the winter season. The confirmation of this hypothesis of faecal-oral transmission can be an early warning tool towards policies and strategies in existing techniques of COVID-19 pandemic control additive to the prominent role of water for handwashing (Heller et al. 2020). The 
current lack of evidence on the importance of the faecaloral transmission of SARS-Cov-2 is highlighted in this study. Moreover, this raises the urgent need of a detailed research to determine the definite role of water and sanitation mediations for prevention of this route of transmission in River Gomti and other surface water sources across the globe.

\section{Conclusion}

The COVID-19 lockdown did not provide any significant improvement in the water quality of the River Gomti. Instead $\sim 69 \%$ of the sites showed deteriorated water quality during the assessment through water quality index computation. The increased WQI value during the lockdown phase at the upstream site RG1 suggested a slight decrease in the water quality highlighting the possible impact of local anthropogenic activities and the absence of any treatment plant in the vicinity. As the river travels towards the sites RG2 and RG3, an improvement in water quality is witnessed, signifying its groundwater fed nature with constant refinement in flow which attributes towards enhanced self-healing capacity. The river witnessed a near constant trend of water quality deterioration in sites within Lucknow city (RG5 to RG10) during all the three sampling periods. This result highlights the influence of urban sprawl and direct discharge of untreated effluents into the river. Moreover, the self-healing capacity of the River Gomti has been adversely affected due to the reduction in its natural flow after the riverfront development in Lucknow city. This assessment of the quality of water in River Gomti during the pre-lockdown, lockdown, and post-lockdown periods clearly shows that the major factor of concern for River Gomti is the sewage discharge which was unaffected during the lockdown. Hence, it can be concluded that the COVID-19 lockdown did not act completely as a ventilator for the revival of River Gomti. Instead, the release of domestic sewage into River Gomti has exposed the population to the risk of virus outbreak through faecal-oral transmission which needs immediate in-depth research to ensure the safety and health of habitants. Thus, the findings of this study call for immediate interventions to stop the direct discharge of domestic waste into the river water to accelerate the self-healing capacity of River Gomti and to restore it to a cleaner state.

\footnotetext{
Acknowledgements Authors highly acknowledge the data availability from UPPCB website. Authors are thankful to Prof. (Dr.) A. K. Singh, Vice-Chancellor, Shri Ramswaroop Memorial University, for support in conduction of this study. The assistance from $\mathrm{Mr}$. Biswajit Das, and Dr. Saurabh Singh is also to be acknowledged. The constant motivation from our families in conduction of this study is to be highly appreciated.
}

Author contribution RK conducted the investigation, developed the suitable methodology, and was involved with the writing (original draft) of the manuscript. AS helped with the conceptualization of the work and provided supervision in the presented work. SS helped with writing (review and editing) and formal analysis of the data. SS helped in review and editing of the manuscript. PG assisted in review and editing of the manuscript.

Data Availability The datasets used and/or analyzed during the current study are available at the online portal.

\section{Declarations}

Ethics approval and consent to participate Not applicable.

Consent for publication Not applicable.

Competing interests The authors declare no competing interests.

\section{References}

Ahmed W, Angel N, Edson J, Bibby K, Bivins A, O'Brien JW, Choi PM, Kitajima M, Simpson SL, Li J, Tscharke B, Verhagen R, Smith WJM, Zaugg J, Dierens L, Hugenholtz P, Thomas KV, Mueller JF (2020) First confirmed detection of SARS-CoV-2 in untreated wastewater in Australia: a proof of concept for the wastewater surveillance of COVID-19 in the community. Sci Total Environ 728: 138764. https://doi.org/10.1016/j.scitotenv.2020.138764

BING (2020) Coronavirus Lucknow, Uttar Pradesh, India - live map tracker from Microsoft Bing. In: 2020. https://bing.com/covid/ local/lucknow uttarpradesh india. Accessed 19 Nov 2020

Das B, Jain S, Singh S, Thakur P (2019) Evaluation of multisite performance of SWAT model in the Gomti River Basin, India. Appl Water Sci 9:3. https://doi.org/10.1007/s13201-019-1013-x

DTE (2020) No major improvement in river water quality during COVID-19 lockdown: CPCB report. https://www.downtoearth. org.in/news/water/nomajor-improvement-in-river-water-qualityduring-covid-19-lockdown-cpcb-report-73520. Accessed 23 Feb 2021

Dutta V, Sharma U, Iqbal K, Adeeba, Kumar R, Pathak AK (2018) Impact of river channelization and riverfront development on fluvial habitat: evidence from Gomti River, a tributary of Ganges, India. Environ Sustain 1:167-184. https://doi.org/10.1007/s42398-0180016-0

Dutta V, Dubey D, Kumar S (2020) Cleaning the River Ganga: Impact of lockdown on water quality and future implications on river rejuvenation strategies. Sci Total Environ 743:140756. https://doi.org/10. 1016/j.scitotenv.2020.140756

Goel P, Saxena A, Singh DS, Verma D (2018) Impact of rapid urbanization on water quality index in groundwater fed Gomati River, Lucknow, India. Curr Sci 114:650-654. https://doi.org/10.18520/ $\mathrm{cs} / \mathrm{v} 114 / \mathrm{i} 03 / 650-654$

Heller L, Mota CR, Greco DB (2020) COVID-19 faecal-oral transmission: are we asking the right questions? Sci Total Environ 729: 138919. https://doi.org/10.1016/j.scitotenv.2020.138919

Khan R, Saxena A, Shukla S (2020) Evaluation of heavy metal pollution for River Gomti, in parts of Ganga Alluvial Plain, India. SN Appl Sci 2:1-12. https://doi.org/10.1007/s42452-020-03233-9

Medema G, Heijnen L, Elsinga G et al (2020) Presence of SARSCoronavirus-2 in sewage. medRxiv. https://doi.org/10.1101/2020. 03.29.20045880 
Mishra S, Kumar A (2020) Estimation of physicochemical characteristics and associated metal contamination risk in the Narmada River, India. Environ Eng Res 26:190521. https://doi.org/10.4491/eer. 2019.521

Prakash K, Singh S, Mohanty T, Chaubey K, Singh CK (2017) Morphometric assessment of Gomati river basin, middle Ganga plain, Uttar Pradesh, North India. Spat Inf Res 25:449-458. https://doi.org/10.1007/s41324-017-0110-x

Selvam S, Jesuraja K, Venkatramanan S, Chung SY, Roy PD, Muthukumar P, Kumar M (2020) Imprints of pandemic lockdown on subsurface water quality in the coastal industrial city of Tuticorin, South India: a revival perspective. Sci Total Environ 738:139848. https://doi.org/10.1016/j.scitotenv.2020.139848

Shukla S, Saxena A (2020a) Appraisal of groundwater quality with human health risk assessment in parts of Indo-Gangetic alluvial plain, North India. Arch Environ Contam Toxicol 80:55-73. https://doi. org/10.1007/s00244-020-00771-6

Shukla S, Saxena A (2020b) Water quality index assessment of groundwater in the Central Ganga Plain with reference to Raebareli district, Uttar Pradesh, India. Curr Sci 119:1308-1315. https://doi.org/10. $18520 / \mathrm{cs} / \mathrm{v} 119 / 18 / 1308-1315$

Shukla S, Saxena A (2020c) Groundwater quality and associated human health risk assessment in parts of Raebareli district, Uttar Pradesh, India. Groundw Sustain Dev 10:100366. https://doi.org/10.1016/j. gsd.2020.100366

Srivastava P, Singh IB, Sharma M, Singhvi AK (2003) Luminescence chronometry and Late Quaternary geomorphic history of the Ganga Plain, India. Palaeogeogr Palaeoclimatol Palaeoecol 197:15-41. https://doi.org/10.1016/S0031-0182(03)00384-5

Tangri AK, Kumar D, Singh DS, Dubey CA (2018) The Gomati River: lifeline of Central Ganga Plain. Springer, Singapore, pp 135-150
UPPCB (2020) UP Pollution Control Board, Lucknow. http://www. uppcb.com/data-of-year-2020.htm. Accessed 26 Aug 2020

Wang W, Xu Y, Gao R et al (2020) Detection of SARS-CoV-2 in different types of clinical specimens. JAMA 323:1843-1844

WHO (2020a) Advice for the public. https://www.who.int/emergencies/ diseases/novel-coronavirus-2019/advice-for-public. Accessed 6 Sep $2020 \mathrm{a}$

WHO (2020b) Modes of transmission of virus causing COVID-19: implications for IPC precaution recommendations. In: 2020. https:// www.who.int/news-room/commentaries/detail/modes-oftransmission-of-virus-causing-covid-19-implications-for-ipcprecaution-recommendations. Accessed 18 Nov 2020b

Worldometer (2020a) Coronavirus cases. In: Worldometer. https://www. worldometers.info/coronavirus/? Accessed 6 Sep 2020

Worldometer (2020b) India population (2020) - Worldometer. https:// www.worldometers.info/world-population/india-population/. Accessed 11 Oct 2020

Wu Y, Guo C, Tang L, Hong Z, Zhou J, Dong X, Yin H, Xiao Q, Tang Y, Qu X, Kuang L, Fang X, Mishra N, Lu J, Shan H, Jiang G, Huang X (2020) Prolonged presence of SARS-CoV-2 viral RNA in faecal samples. Lancet Gastroenterol Hepatol 5:434-435

Yunus AP, Masago Y, Hijioka Y (2020) COVID-19 and surface water quality: improved lake water quality during the lockdown. Sci Total Environ 731:139012. https://doi.org/10.1016/j.scitotenv.2020. 139012

Publisher's note Springer Nature remains neutral with regard to jurisdictional claims in published maps and institutional affiliations. 